\title{
Screening of french bean (Phaseolus vulgaris $L$.) genotypes for high yield potential
}

\author{
F. Noor ${ }^{1^{*}}$, F. Hossain ${ }^{1}$ and U. Ara ${ }^{2}$ \\ ${ }^{1}$ Department of Botany, Jahangirnagar University, Savar, Dhaka-1342,Bangladesh and \\ ${ }^{2}$ Institute of Food Science \& Technology, Bangladesh Council of Scientific and Industrial Research (BCSIR), \\ Dhaka
}

\begin{abstract}
Eleven genotypes of french bean (Phaseolus vulgaris L.) were screened to select a suitable one which could provide optimum yield of fresh pod, dry seed and biochemical parameters. The maximum seed yield in french bean was found in case of genotype BB-9 (2.96 t/ha) and BARI bush bean -1 (2.95 t/ha), while that of minimum was found in BB-11(1.64 t/ha). However, maximum fresh pod yield (14.25 t/ha) was found for BARI bush bean -1 , followed by BARI bush bean -2 (13.23t/ha). BARI bush bean -1 required the minimum time of 88.33 days while BB-3 the maximum of 110.00 days to attain $90 \%$ pods maturity. The highest number of diseased plants were observed in BB- 5 $(30.33 \%)$ and the lowest were in BARI bush bean $-1(7.33 \%)$. No significant difference $(\mathrm{P}<0.05)$ in maximum protein content among the studied genotypes was observed, for example BB-15 (21.60\%) and BARI bush bean -1 (21.57\%). Maximum crude fiber (5.53\%) was obtained from BARI bush bean -1, followed by BB-6 (5.50\%), BB-20 (5.50\%) and BB-5 (5.47\%), which all were statistically similar. Among all the genotypes, BARI bush bean -1 showed highest yield and superior quality of french bean.
\end{abstract}

Key words: Screening; French bean; Genotypes; Yield; Seed proximate

\section{Introduction}

In Bangladesh, the estimated area and production of pulse and vegetables are not sufficient to meet the demand of balanced diet for the increasing population. In the year 2007-2008, the cultivated areas were about $1.63 \%, 76.98 \%$, $2.79 \%$ and $2.89 \%$ for pulse, rice, wheat and vegetables respectively (Anomymous, 2009). Pulse and vegetables crop areas as well as selected high yielding variety like french bean have to be extended in order to increase yield of fresh bean and seed production for solving malnutrition problems of this country. Very few studies have been carried out regarding characterization, spacing and sowing time in Bangladesh (Mozumder et al. 2003; Roy, 2004 and Hussain 2005). Therefore, the aim and objectives of this study is to select one genotype of french bean, which requires shortest time for 4 leaves stages, $90 \%$ flowering, pod setting and maturation, gives highest yields of pods and seeds with better biochemical parameters.

\section{Materials and methods}

Nine french bean genotypes with the accession numbers, BB-3, BB-5, BB-6, BB-9, BB-10, BB-11, BB-14, BB-15 and BB-20 were collected from Agronomy Division, Bangabandhu Sheikh Mujibur Rahman Agricultural University, Gazipur. Two varieties namely BARI bush bean -1 and BARI bush bean -2 also was collected from
Bangladesh Agricultural Research Institute (BARI), Gazipur.

The soil samples were analyzed at the Soil Research and Development Institute (SRDI), Farmgate, Dhaka according the Fertilizer Recommendation Guide (Anomymous, 2005).

Field experiment was carried out at the research field of Bangladesh Council of Scientific and Industrial Research (BCSIR), Dhaka, in the Rabi season during November 2007 to March 2008 in a randomized complete block design (RCBD) with three replications. The unit plot size was $2.0 \mathrm{~m}$ x $1.5 \mathrm{~m}$. Cow dung was applied 6.67 t/ha and Nitrogen, phosphorous, potassium, boron and sulphur were applied as per the recommendation of Fertilizer Recommendation Guide (2005). The seeds were sown with the spacing $30 \mathrm{~cm}$ $\mathrm{x} 15 \mathrm{~cm}$ in line and about $3.0 \mathrm{~cm}$ in depth and covered with pulverized soil and pressed gently by hand (Mozumder 2002). The sowing was done on 20 November, 2007 and then the plots were watered slightly in the line to supply sufficient moisture for quick germination. Weeding was done at 15 days interval. The crop was protected by spraying Malathion 57 EC @ $2 \mathrm{ml} / \mathrm{L}$ as per recommendation of BARI (Anomymous, 1995). Furrow irrigation was given at an interval of 7 to 10 days depending on soil moisture content.

Plant height, number of leaves, leaf area (Gardner et al.

\footnotetext{
*Corresponding author: E-mail: panna.noor@gmail.com
} 
1988), leaf area index (Radford, 1967 and Watson, 1952), disease incidence (Khandaker et al. 2011), pod length, number of pods/plant, number of seeds/pod, 1000 seed weight, fresh pod yield g/plant, seed yield g/plant were measured from ten randomly selected plants for each genotype at the harvest. Data on fresh pod yield $t / h a$, seed yield ( $\mathrm{t} / \mathrm{ha}$ ) and harvest index were taken from the samples of the pre-demarcated area of each plot according to Ullah (Ullah 2006). Days to 4 leaves stage, 90\% flowering, pod setting and maturity of pods were counted when each physiological character was appeared in a genotype.

Quantitative determination of moisture, crude protein, crude fiber, crude fat, ash and carbohydrate of dry seeds were done according to Association of Official Analytical Chemist (AOAC) (Anomymous, 2005).

\section{Statistical analysis}

All the data collected on various parameters were statistically analyzed by SPSS (version 13) and MS Excel programme. Analysis of variance for each of the parameters was performed by $\mathrm{F}$ test. Co-efficient of variation (CV\%), Duncan's Multiple Range Test (DMRT) and Least Significant Difference (LSD) test at 5\% level of significance were done according to Gomez and co-warkers (Gomez and Gomez, 1984).

\section{Results and discussion}

Results presented in Table I. show that the plant height varied enormously from genotype to genotype. It ranged from 25.61
(BB-20) to $60.83 \mathrm{~cm}$ (BB-9). This might be due to genetic configuration and environmental effect. It was studied that (Hussain, 2005) for ten genotypes of bush bean who found the tallest plant in BB-9 $(40.78 \mathrm{~cm})$ and the shortest in BB-1 $(20.50 \mathrm{~cm})$. He also reported that the time of sowing had significant effect on plant height of bush bean.

Genotypic differences was observed in number of leaves, leaf area and leaf area index. The maximum number of leaves (21.67), leaf area $(2165.26 \mathrm{~cm} 2)$ and leaf area index (4.81) were recorded for BB-9 and the minimum was for BB-11 (9, $855.18 \mathrm{~cm} 2$ and 1.90 respectively) (Table I). These variations might be due to difference in genetical constituents as well as environmental effects.

Marked differences in diseased plants were observed in all eleven genotypes of french bean. The highest number of diseased plant was recorded in BB-5 (30.33\%) and the lowest in BARI bush bean -1 (7.33\%) (Table I). It has been (Hussain, 2005) reported that percentages of disease plants were influenced by sowing time of bush bean. The lowest number of disease plants was observed with 15 December sowing.

It was observed that BARI bush bean -1 took the shortest time to attain 4 leaves stage (17.33 days), whereas the genotype BB-3 took the longest (23.00 days) (Figure 1). These results concur with the findings of Roy (Roy, 2004) who also observed marked variation (15.00 to 21.67 days) among the genotypes in respect of days required to attain 4 leaves stage of bush bean genotypes.

Table I. Mean performance of different physiological characters of eleven genotypes of french bean

\begin{tabular}{lccccc}
\hline Genotypes & $* *$ Plant height $(\mathrm{cm})$ & $* *$ Number of leaves & $* *$ Leaf area $(\mathrm{cm} 2)$ & $* *$ Leaf area Index $($ LAI $)$ & Disease incidence $(\%)$ \\
\hline BB-3 & $46.30 \mathrm{~b}$ & $21.00 \mathrm{a}$ & $1211.83 \mathrm{c}$ & $2.69 \mathrm{c}$ & $20.33 \mathrm{~d}$ \\
BB-5 & $41.50 \mathrm{~d}$ & $19.00 \mathrm{~b}$ & $1058.43 \mathrm{f}$ & $2.35 \mathrm{f}$ & $30.33 \mathrm{a}$ \\
BB-6 & $37.53 \mathrm{f}$ & $18.33 \mathrm{~b}$ & $963.13 \mathrm{~h}$ & $2.14 \mathrm{~h}$ & $22.33 \mathrm{c}$ \\
BB-9 & $60.83 \mathrm{a}$ & $21.67 \mathrm{a}$ & $2165.26 \mathrm{a}$ & $4.81 \mathrm{a}$ & $14.00 \mathrm{f}$ \\
BB-10 & $40.53 \mathrm{e}$ & $12.67 \mathrm{~d}$ & $1032.10 \mathrm{~g}$ & $2.29 \mathrm{~g}$ & $19.33 \mathrm{~d}$ \\
BB-11 & $41.10 \mathrm{~d}$ & $9.00 \mathrm{e}$ & $855.18 \mathrm{i}$ & $1.90 \mathrm{i}$ & $19.33 \mathrm{~d}$ \\
BB-14 & $35.17 \mathrm{~h}$ & $14.00 \mathrm{c}$ & $1309.37 \mathrm{~b}$ & $2.91 \mathrm{~b}$ & $14.45 \mathrm{f}$ \\
BB-15 & $43.27 \mathrm{c}$ & $14.00 \mathrm{c}$ & $1116.51 \mathrm{e}$ & $2.48 \mathrm{e}$ & $14.33 \mathrm{f}$ \\
BB-20 & $25.61 \mathrm{j}$ & $14.00 \mathrm{c}$ & $1136.33 \mathrm{~d}$ & $2.52 \mathrm{~d}$ & $26.00 \mathrm{~b}$ \\
BARI bush bean-1 & $36.05 \mathrm{~g}$ & $11.67 \mathrm{~d}$ & $1207.28 \mathrm{c}$ & $2.68 \mathrm{c}$ & $7.33 \mathrm{~g}$ \\
BARI bush bean-2 & $28.23 \mathrm{i}$ & $11.67 \mathrm{~d}$ & $1205.33 \mathrm{c}$ & $2.68 \mathrm{c}$ & $16.67 \mathrm{e}$ \\
LSD $(0.05)$ & 0.52 & 1.10 & 12.71 & 0.03 & 1.22 \\
CV\% & 22.88 & 26.83 & 27.57 & 27.57 & 33.01 \\
\hline
\end{tabular}

*Means in a column followed by the same letter do not differ significantly at $5 \%$ level;

**At $50 \%$ pod setting stage 


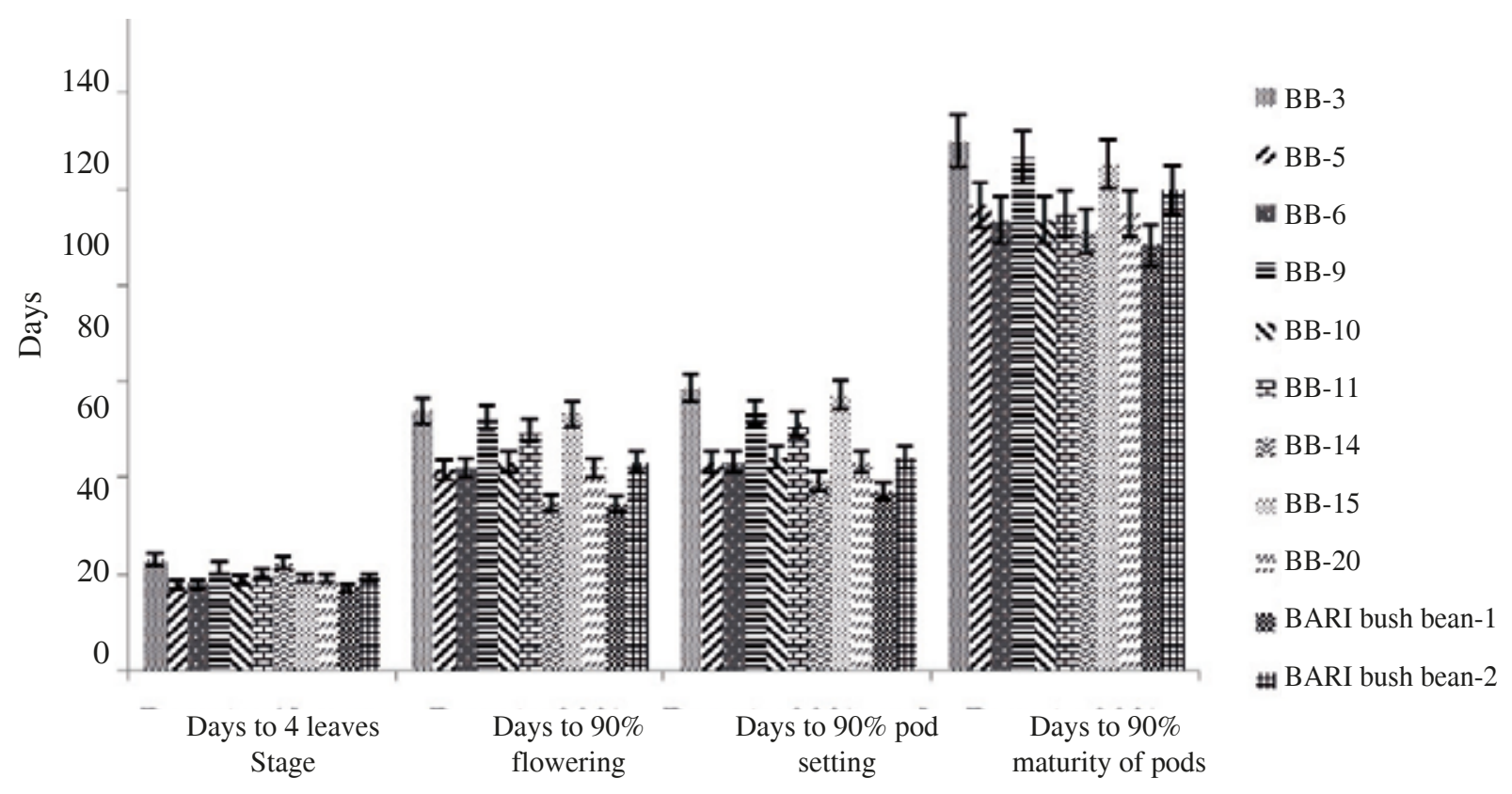

Fig . 1. Mean performances for days to 4 leaves stages, $90 \%$ flowering, $90 \%$ pod setting and $90 \%$ maturation of pods of eleven genotypes of french bean (Mean \pm Standard Error).

Genotypic variation was also observed in days to attain $90 \%$ flowering (Figure 1). BARI bush bean -1 (34.67) and BB-15 (35.00) took minimum days, whereas BB-3 (54.00) and BB-9 (52.67) took maximum days to $90 \%$ flowering. In a varietal trial of french bean, Joshi et al. (1987) reported that the varieties required 45-46 days to attain 50\% flowering, which was in consonance with the majority of varieties under investigation.

Days to $90 \%$ pod setting was significantly varied $(\mathrm{P}<0.05)$ in different genotypes (Figure 1). The genotypes BB-3 (58.67) and BB-15 (57.33) required maximum days, whereas BARI bush bean -1 (37.33) required minimum days for $90 \%$ pod setting.

Minimum days for $90 \%$ maturation of pods (88.33 days) were recorded in BARI bush bean -1 and maximum in BB-3 (110 days) $(\mathrm{P}<0.05)$ (Figure 1), whereas Thamburaj et al. (1980) reported that duration of the crop ranged from 64 to 98 days in thirty genotypes of bush bean.

Pod length ranged from 6.51 (BB-3) to $13.23 \mathrm{~cm}$ (BARI bush bean -1) (Table II). These findings agree well with those of report (Mozumder et al., 1996) who found wide variation (8.9 to $17.7 \mathrm{~cm}$ ) in pod length of bush bean genotypes.

Number of pods per plant ranged from 7.33 to 20.67 (Table II). The maximum number of pods per plant was recorded in
BB-3 (20.67) and BB-15 (20.00), which were statistically identical. The minimum number of pods per plant was

Table II. Yield attributes showing mean performance of eleven genotypes

\begin{tabular}{|c|c|c|c|c|}
\hline Genotypes & $\begin{array}{l}\text { Pod } \\
\text { length } \\
(\mathrm{cm})\end{array}$ & $\begin{array}{c}\text { Number of } \\
\text { pods/ } \\
\text { plant }\end{array}$ & $\begin{array}{l}\text { Number } \\
\text { of seeds/ } \\
\text { pod }\end{array}$ & $\begin{array}{c}1000 \\
\text { Seed } \\
\text { weight } \\
(\mathrm{g})\end{array}$ \\
\hline BB-3 & $6.51 \mathrm{j}$ & $20.67 \mathrm{a}$ & $5.44 b$ & $135.75 \mathrm{~h}$ \\
\hline BB-5 & $10.03 \mathrm{e}$ & $11.00 \mathrm{c}-\mathrm{e}$ & $4.22 \mathrm{e}$ & $233.18 d$ \\
\hline BB-6 & $9.76 f$ & $10.00 \mathrm{de}$ & $4.00 \mathrm{f}$ & $204.43 f$ \\
\hline BB-9 & $9.36 \mathrm{~g}$ & $16.67 b$ & $5.00 \mathrm{c}$ & $199.13 \mathrm{~g}$ \\
\hline BB-10 & $12.51 \mathrm{c}$ & $9.00 \mathrm{ef}$ & $4.20 \mathrm{e}$ & $278.39 b$ \\
\hline BB-11 & $8.44 \mathrm{~h}$ & $12.00 \mathrm{~cd}$ & $5.43 b$ & $116.38 \mathrm{i}$ \\
\hline BB-14 & $10.19 \mathrm{de}$ & $12.97 \mathrm{c}$ & $4.65 d$ & $249.90 c$ \\
\hline BB-15 & $7.09 \mathrm{i}$ & $20.00 \mathrm{a}$ & $5.45 b$ & $134.00 \mathrm{~h}$ \\
\hline BB-20 & $12.73 b$ & $7.33 \mathrm{f}$ & $3.88 \mathrm{~g}$ & $368.50 \mathrm{a}$ \\
\hline BARI bush bean- 1 & $13.23 \mathrm{a}$ & $12.23 \mathrm{c}$ & $5.80 \mathrm{a}$ & $212.47 \mathrm{e}$ \\
\hline BARI bush bean- 2 & $10.32 \mathrm{~d}$ & $10.00 \mathrm{de}$ & $5.00 \mathrm{c}$ & $199.00 \mathrm{~g}$ \\
\hline $\operatorname{LSD}(0.05)$ & 0.19 & 2.016 & 0.05 & 3.04 \\
\hline $\mathrm{CV} \%$ & 21.18 & 33.84 & 13.48 & 33.02 \\
\hline
\end{tabular}

*Means in a column followed by the same letter do not differ significantly at $5 \%$ level. 
recorded in BB-20 (7.33). These results are at variance with the findings of singh and co-workers (Singh et al., 1992), who reported that the number of pods per plant in french bean genotypes varied from 10 to 12 .

Number of seeds per pod significantly varied depending on the genotypes (Table II). The highest number of seeds per pod was obtained for BARI bush bean -1 (5.80), whereas the lowest was for BB-20 (3.88). Roy (2004) found higher number of seeds per pod in BB-3 (5.74), BARI bush bean -1 (5.45), BB-15 (5.32), BB-11 (5.16) and BB-14 (5.07), and the lower in BB-22 (1.84) and BB-26 (1.86).

Significant variations $(\mathrm{P}<0.05)$ in 1000 seed weight were observed in the genotypes. The highest seed weight was recorded in BB-20 (368.50 g) and the lowest in BB-11

Table III. Yield and yield attributes showing mean performance of eleven genotypes of french bean

\begin{tabular}{lccccc}
\hline Genotypes & $\begin{array}{c}\text { Fresh pod } \\
\text { yield /plant }(\mathrm{g})\end{array}$ & $\begin{array}{c}\text { Fresh pod } \\
\text { yield }(\mathrm{t} / \mathrm{ha})\end{array}$ & $\begin{array}{c}\text { Seed yield } / \\
\text { plant }(\mathrm{g})\end{array}$ & $\begin{array}{c}\text { Seed yield } \\
(\mathrm{t} / \mathrm{ha})\end{array}$ & $\begin{array}{c}\text { Harvest } \\
\text { Index }(\%)\end{array}$ \\
\hline BB-3 & $59.33 \mathrm{~b}$ & $13.19 \mathrm{~b}$ & $11.47 \mathrm{c}$ & $2.55 \mathrm{c}$ & $49.32 \mathrm{c}$ \\
BB-5 & $43.33 \mathrm{ef}$ & $9.63 \mathrm{ef}$ & $10.07 \mathrm{~d}$ & $2.24 \mathrm{~d}$ & $45.44 \mathrm{~d}$ \\
BB-6 & $41.00 \mathrm{fg}$ & $9.11 \mathrm{fg}$ & $8.08 \mathrm{f}$ & $1.80 \mathrm{f}$ & $38.86 \mathrm{e}$ \\
BB-9 & $52.98 \mathrm{c}$ & $11.77 \mathrm{c}$ & $13.30 \mathrm{a}$ & $2.96 \mathrm{a}$ & $54.51 \mathrm{a}$ \\
BB-10 & $48.34 \mathrm{~d}$ & $10.743 \mathrm{~d}$ & $10.08 \mathrm{~d}$ & $2.24 \mathrm{~d}$ & $45.44 \mathrm{~d}$ \\
BB-11 & $39.37 \mathrm{~g}$ & $8.75 \mathrm{~g}$ & $7.40 \mathrm{~g}$ & $1.64 \mathrm{~g}$ & $36.17 \mathrm{f}$ \\
BB-14 & $61.17 \mathrm{ab}$ & $13.59 \mathrm{ab}$ & $12.37 \mathrm{~b}$ & $2.75 \mathrm{~b}$ & $51.40 \mathrm{~b}$ \\
BB-15 & $52.50 \mathrm{c}$ & $11.67 \mathrm{c}$ & $11.50 \mathrm{c}$ & $2.56 \mathrm{c}$ & $49.41 \mathrm{c}$ \\
BB-20 & $44.35 \mathrm{e}$ & $9.86 \mathrm{e}$ & $9.87 \mathrm{e}$ & $2.19 \mathrm{e}$ & $44.90 \mathrm{~d}$ \\
BARI bush bean-1 & $64.13 \mathrm{a}$ & $14.25 \mathrm{a}$ & $13.27 \mathrm{a}$ & $2.95 \mathrm{a}$ & $54.49 \mathrm{a}$ \\
BARI bush bean-2 & $59.53 \mathrm{~b}$ & $13.23 \mathrm{~b}$ & $9.90 \mathrm{e}$ & $2.20 \mathrm{e}$ & $44.93 \mathrm{~d}$ \\
LSD 0.05$)$ & 3.05 & 0.68 & 0.09 & 0.02 & 0.59 \\
CV\% & 16.74 & 16.73 & 17.53 & 17.53 & 12.07 \\
\hline
\end{tabular}

*Means in a column followed by the same letter do not differ significantly at $5 \%$ level.

Table IV. Seed proximate contents of french bean genotypes

\begin{tabular}{lccccc}
\hline Genotypes & $\begin{array}{c}\text { Carbohydrate } \\
(\%)\end{array}$ & $\begin{array}{c}\text { Crude protein } \\
(\%)\end{array}$ & $\begin{array}{c}\text { Crude fiber } \\
(\%)\end{array}$ & $\begin{array}{c}\text { Ash } \\
(\%)\end{array}$ & $\begin{array}{c}\text { Crude fat } \\
(\%)\end{array}$ \\
\hline BB-3 & $66.35 \mathrm{e}$ & $21.30 \mathrm{~b}$ & $5.11 \mathrm{c}$ & $5.47 \mathrm{a}$ & $1.77 \mathrm{c}$ \\
BB-5 & $67.42 \mathrm{~d}$ & $21.03 \mathrm{c}$ & $5.47 \mathrm{a}$ & $4.27 \mathrm{e}$ & $1.81 \mathrm{bc}$ \\
BB-6 & $68.06 \mathrm{c}$ & $19.24 \mathrm{~g}$ & $5.50 \mathrm{a}$ & $5.35 \mathrm{~b}$ & $1.84 \mathrm{~b}$ \\
BB-9 & $67.97 \mathrm{c}$ & $20.93 \mathrm{c}$ & $4.87 \mathrm{e}$ & $4.40 \mathrm{~d}$ & $1.83 \mathrm{bc}$ \\
BB-10 & $69.45 \mathrm{a}$ & $20.34 \mathrm{e}$ & $4.69 \mathrm{~g}$ & $4.13 \mathrm{~g}$ & $1.40 \mathrm{f}$ \\
BB-11 & $68.10 \mathrm{c}$ & $20.70 \mathrm{~d}$ & $5.33 \mathrm{~b}$ & $4.30 \mathrm{e}$ & $1.57 \mathrm{~d}$ \\
BB-14 & $69.14 \mathrm{~b}$ & $20.36 \mathrm{e}$ & $4.80 \mathrm{ef}$ & $4.20 \mathrm{f}$ & $1.50 \mathrm{e}$ \\
BB-15 & $65.92 \mathrm{f}$ & $21.60 \mathrm{a}$ & $5.00 \mathrm{~d}$ & $5.45 \mathrm{a}$ & $2.03 \mathrm{a}$ \\
BB-20 & $69.43 \mathrm{a}$ & $19.75 \mathrm{f}$ & $5.50 \mathrm{a}$ & $3.90 \mathrm{~h}$ & $1.42 \mathrm{f}$ \\
BARI bush bean-1 & $66.58 \mathrm{e}$ & $21.57 \mathrm{a}$ & $5.53 \mathrm{a}$ & $4.52 \mathrm{c}$ & $1.80 \mathrm{bc}$ \\
BARI bush bean-2 & $69.26 \mathrm{~b}$ & $20.35 \mathrm{e}$ & $4.73 \mathrm{fg}$ & $4.17 \mathrm{fg}$ & $1.49 \mathrm{e}$ \\
LSD 0.05$)$ & 0.25 & 0.22 & 0.08 & 0.05 & 0.06 \\
CV\% & 1.84 & 3.50 & 6.39 & 12.29 & 12.29 \\
\hline
\end{tabular}

*Means in a column followed by the same letter do not differ significantly at $5 \%$ level 
(116.38 g) (Table II). The findings of the present study are comparable to those of Dwivedi et al. (1995) who found minimum 100 seed weight in Rajmah (46.08 g) and maximum in Contender (63.63 g).

That the highest fresh pod yield was recorded in BARI bush bean -1 (64.13 $\mathrm{g}$ and $14.25 \mathrm{t} / \mathrm{ha})$, followed by BARI bush bean $-2(59.53 \mathrm{~g}$ and $13.23 \mathrm{t} / \mathrm{ha})(\mathrm{P}<0.05)$, which are more suitable for human consumption than those of nine other genotypes (Table III). Chowdhury and co-workers (Chowdhury and Faruque 1973) reported about a genotype of Phaseolus vulgaris, which is bushy type; the pods are extremely rough with hard tissue and not suitable for use as green vegetable. Thamburaj co-workers (Thamburaj et al., 1980) reported wide variations in green pod yield varied from 7.69 to $15.5 \mathrm{t} / \mathrm{ha}$.

Seed yield depended on genotypes. The maximum seed yield was obtained from BB-9 (13.30 g and $2.96 \mathrm{t} / \mathrm{ha}$ ), followed by BARI bush bean -1 (13.27 $\mathrm{g}$ and $2.95 \mathrm{t} / \mathrm{ha})$ and minimum in BB-11 (7.40 g and $1.64 \mathrm{t} / \mathrm{ha}$ ) (Table III). The harvest index (HI) ranged from 36.17 to $54.51 \%(\mathrm{P}<0.05)$. The highest value for harvest index was recorded in BB-9 (54.51\%) and BARI bush bean $-1(54.49 \%)$ and, the lowest in BB-11 (36.17\%). Chowdhury and co-workers (Chowdhury and Faruque 1973) studied a genotype of Phaseolus vulgaris, which produced a good yield of seed (1.8 t/ha). Ahlawat and Sharma (1989) studied a genotype PDR 14 of french bean, which had good growth and gave higher seed yield (1.48 t/ha).

Among the genotypes, the maximum crude protein $(21.60 \%)$ was found in BB-15 and BARI bush bean -1 (21.57\%), which were statistically identical and the minimum was in BB-6 (19.24\%) (Table IV) $(\mathrm{P}<0.05)$. Maximum crude fiber $(5.53 \%)$ was obtained from BARI bush bean -1 , followed by BB-6 (5.50\%), BB-20 (5.50\%) and BB-5 (5.47\%), which were statistically similar and the minimum was from BB-10 $(4.69 \%)(\mathrm{P}<0.05)$. The ash content was highest in BB-3 $(5.47 \%)$ and BB-15 (5.45\%), whereas the lowest was in BB-20 (3.90\%). The crude fat was highest in BB-15 $(2.03 \%)$ and the lowest was in $\mathrm{BB}-10(1.40 \%)(\mathrm{P}<0.05)$. In addition, the carbohydrate content was maximum in BB-10 $(69.45 \%)$ and BB-20 (69.43\%) and minimum in BB-15 $(65.92 \%)$ (Table IV). Shanmugavelu (Shanmugavelu 1989) reported that dry seeds of french bean contained $23.1 \%$ protein, $1.7 \%$ fat and 59\% carbohydrate (Shanmugavelu 1989).

\section{Conclusion}

The results of the study show that out of the eleven genotypes, the highest fresh pod yield was obtained from BARI bush bean-1 (14.25 t/ha). The highest seed yield was recorded for BB-9 (2.96 t/ha), which was followed by BARI bush bean-1 (2.95 t/ha). BARI bush bean-1 took minimum time for $90 \%$ flowering (34.67 days), $90 \%$ pod setting (37.33 days), and $90 \%$ maturity of pods (88.33 days).The lowest number of diseased plant was observed in BARI bush bean-1 (7.33\%). Moreover, the maximum crude protein $(21.57 \%)$ and crude fiber $(5.53 \%)$ were obtained from BARI bush bean-1. Therefore, BARI bush bean-1 was selected as best for its quality and yields (fresh pod and dry seed) among eleven genotypes of french bean .

\section{References}

Ahlawat I P S and Sharma R P (1989), Response of French bean genotypes to soil moisture regimes and phosphate fertilization. Indian J. Agron. 34: 70-74.

Anomymous, AOAC (2005), Official methods of analysis of AOAC International. 18th edition, Suite 500, 481 North Frederick Avenue, Gaithersburg, Maryland 20877-2417, USA.

Anomymous, BARI (Bangladesh Agricultural Research Institute) (1995), Annual Report for 1993-1994. BARI, Joydebpur, Gazipur, Bangladesh.

Anomymous, BBS (Bangladesh Bureau of Statistics) (2009), Yearbook of Agricultural Statistics of Bangladesh 2008. Bangladesh Bureau of Statistics, Statistics Division, Ministry of Planning, Govt. of the People's Republic of Bangladesh.www.bbs.gov.bd

Chowdhury A T M S and Faruque A H M (1973), Pinto, a new variety of bean for Bangladesh. Bangladesh Hort. 1: 37-38.

Dwivedi Y C, Sharma R S and Sharma R K (1995), Advances in Agril. Res. in India. 4: 65-72.

Anomymous, Fertilizer Recommendation Guide (2005), Published by Bangladesh Agricultural Research Council, Farmgate, and New Airport Road.Dhaka-1215.

Gardner F P, Pearce R B and Mitchell R L 1988, Physiology of Crop Plants. Scientific Publishers, Jodhpur.

Gomez K A and Gomez A A 1984, Statistical procedures for agricultural research.2nd edition. John Wiley, New York.

Hussain M M (2005), Yield and quality of bush bean (Phaseolus vulgaris L.) genotypes as influenced by date of sowing. Master of Science (M.S.) Thesis, 
Department of Agronomy, Bangabandhu Seikh Mujibur Rahman Agricultural University (BSMRAU), Salna, Gazipur.

Joshi B D, Sanwal T D and Vidyasagar 1987. 'V L Bauni 1' French bean for the hills. Indian Hort. 31: 5-8.

Khandaker M M, Khair A and Bhuiyan M K A (2011), Disease reaction of potato germplasms and true potato seeds against Rhizoctonia solani Kuhn. Bangladesh J. Bot. 40(2): 193-196.

Mozumder S N, Moniruzzaman M, Islam M R and Alam S N (2003), Effect of planting time and spacing on the yield performance of Bushbean (Phaseolus vulgaris L.) in the eastern hilly area of Bangladesh. Legume Res. (IF 0.135, India). 26(4): 242-247.

Mozumder M A, Rouf M A, Mollah M S and Rashid M A (1996), Collection and evaluation of bush bean germplasms. Research Report on Vegetable Crops, HRC, RARS, Hathazari. (Ed. M.A.Rashid): pp. 35-39.

Mozumder S N (2002), Improved cultivation of Bush bean. BARI (Bangladesh Agricultural Research Institute) Folder No 03/2002.

Purseglove J W (1974), Tropical Crops: Dicotyledons, English Language Book Society/Longman, Longman Singapore Publishers. pp. 132-136.

Radford P J (1967), Growth analysis formulae: their use and abuse. Crop Sci. 7:171-175.
Roy S K (2004), Characterization and yield variation in bush bean (Phaseolus vulgaris L.) genotypes. Master of Science (M.S.) Thesis, Department of Agronomy, Bangabandhu Seikh Mujibur Rahman Agricultural University (BSMRAU), Salna, Gazipur.

Shanmugavelu K G (1989), Production technology of vegetable crops. Oxford \& IBH publishing Co. Pvt. Ltd. New Delhi. pp. 446-461.

Singh R C, Singh M and Kumar R (1992), Performance of French bean genotypes on different sowing date in autumn. Haryana Agric. Univ. J. Res. 22 : 31-34.

Thamburaj S, Shanmugavelu K G, Chokalingam P and Pillai O A A (1980), Varietal evaluation in bush beans (Phaseolus vulgaris L.). South Indian Hort. 28: 113-115.

Ullah M J (2006), Physiological and biochemical responses of cowpea (Vigna unguiculata (L.) Walp.) following the application of growth regulators. $\mathrm{Ph}$. D. Thesis. Dept. of Botany, Jahangirnagar Univ., Savar, Dhaka, Bangladesh. p. 280.

Watson D J (1952), The Physiological basis of variation in yield. Adv.gron. 4: 101145.

Received: 24 December 2012; Revised: 28 August 2014; Accepted: 22 December 2014. 